\title{
UNCHAINING THE LAW: THE LEGALITY OF EXTRATERRITORIAL ABDUCTION IN LIEU OF EXTRADITION
}

\author{
MrtChell J. MATORIN
}

\section{INTRODUCTION}

Extradition treaties and other conventional inethods of international cooperation have proven ineffective in the fight against international terrorisin and narco-terrorisin. Since 1988, the U.S. government has resorted to unilateral measures to bring terrorists and other suspects to trial in the United States. The Court of Appeals for the Ninth Circuit, however, recently undernined the government's efforts by refusing to exercise jurisdiction over suspects not seized in accordance with an asylum state's wishes. This rule would deal a serious blow to the government's ability to coinbat crimes that have reinained notoriously impervious to the current international law enforcennent regime.

The 1985 kidnapping, torture, and murder of Drug Enforceinent Agency (DEA) Special Agent Enrique Cannarena-Salazar provides a case in point. Cainarena was kidnapped by inembers of a Latin American drug cartel; his inutilated body was found one month after he disappeared. ${ }^{1}$ The murder resulted in political tension between the governinents of the Umited States and Mexico because of the perception that the Mexican government had not done enough to bring Cainarena's killers to justice. $^{2}$ In the face of this lack of progress, the DEA embarked on a prograin to bring Camarena's murderers to the Umited States for trial.

1. The murder and subsequent activities attracted much attention and created tension between the United States and Mexico, with the United States clamping down on border traffic between the two countries in an attenipt to pressure Mexico to take quick action to resolve the case. See Mexico Asks U.S. to Cease Lengthy Border Inspections; Says Delays Won't Resolve the Problem, L.A. TIMES, Feb. 21, 1985, at 2.

2. See Storm Arises over Camarena; U.S. Wants Harder Line Adopted, LATIN AM. WKLY. REP., Mar. 8, 1985, at 10 ("DEA head Francis Mullen has charged that the Mexican police deliberately let a key suspect ... slip tlirough their fingers. 'Mexico hasn't arrested a niajor drug trafficker in eight years,' added an angry Mullen."); see also Mexico's President Comes Calling, 132 Cong. REC. 11,462 (1986) (statement of Sen. Hawkins):

The thing that rankles me most about Mexico is how it pussyfoots around on the subject of drug trafficking and corruption in high places. Drug dealers operate with impunity, without the slightest fear that they will be caught. And if they are unlucky enough to be caught in one of the occasional nets Mexican authorities cast from tinie to time, nothing ever Id.

happens. They are never prosecuted. They are released with at most a slap on the wrist. 
Ultimately, a number of suspects were captured, three of them through irregular methods. Dr. Humberto Alvarez-Machain and Rene Martin Verdugo-Urquidez were abducted from Mexico and delivered to the United States; Juan Ramon Matta-Ballesteros was abducted from Honduras. $^{3}$

In United States v. Verdugo-Urquidez (Verdugo II) ${ }^{4}$ and subsequently in United States v. Alvarez-Machain, ${ }^{5}$ the defendants claimed that the abductions violated the U.S.-Mexico Extradition Treaty. ${ }^{6}$ The Nimth Circuit agreed and held that this violation, combined with Mexico's protest of the abductions, stripped the court of its jurisdiction over the cases. The court remanded Verdugo II for a determination of the nature of the U.S. involvement in the abduction, with instructions that if the abduction had been conducted or authorized by the U.S. government, then Verdugo-Urquidez was to be repatriated to Mexico. In Alvarez, the Ninth Circuit also ordered repatriation based on its reasoming in Verdugo II and the evidence of U.S. mvolvement. Both decisions were appealed to the Supreme Court, which granted certiorari in Alvarez to decide whether a person has a right not to be tried in U.S. courts when he is brought before the court im a manner other than that provided im a valid extradition treaty. ${ }^{7}$

3. The circumstances of the abductions differ. Alvarez-Machain was abducted only after negotiations with the Mexican police over the possibility of an informal extradition, during which the Mexican police officials demanded $\$ 50,000$ for their "expenses." The negotiations eventually failed altogetler. United States v. Caro-Quintero, 745 F. Supp. 599, 602-03 (C.D. Cal. 1990), aff'd sub nom. United States v. Alvarez-Machain, 946 F.2d 1466 (9th Cir. 1991), cert. granted, 60 U.S.L.W. 3376 (U.S. Jan. 10, 1992) (No. 91-712). No such negotiations took place before the abduction of Verdugo-Urquidez. Also, the U.S. government was admittedly involved in the Alvarez-Machain abduction, while its role in the Verdugo-Urquidez kidnapping is unclear. For a detailed discussion of the circumstances surrounding the abductions, see Abraham Abramovsky, Extraterritorial Abductions: America's “Catch and Snatch" Policy Run Amok, 31 VA. J. INT'L L. 151 (1991).

4. 939 F.2d 1341 (9th Cir. 1991), petition for cert. filed, 60 U.S.L.W. 3341 (U.S. Oct. 21, 1991) (No. 91-670) (Verdugo II). In an earlier stage, the same case was appealed to the Supreme Court on a Fourth Amendnient searcl and seizure issue. U.S. agents had conducted a search of VerdugoUrquidez's lione in Mexico with the cooperation of Mexican officials, but without a search warrant. The Ninth Circuit held tliat the evidence so seized was inadnissible. The Supreme Court reversed, holding that the Fourth Amendnent did not apply to aliens abroad. See United States v. VerdugoUrquidez, 494 U.S. 259 (1990) (Verdugo I).

5. 946 F.2d 1466 (9th Cir. 1991), cert. granted, 60 U.S.L.W. 3376 (U.S. Jan. 10, 1992) (No. 91-712). The Verdugo II case is on loold pending the decision in Alvarez. Certiorari was likely granted in Alvarez instead of Verdugo II because the extent of United States involvennent in the abduction of Alvarez-Machain was clear, while in Verdugo $I I$ it was not.

6. Extradition Treaty, May 4, 1978, U.S.-Mexico, 31 U.S.T. 5061.

7. The Seventh Circuit denied a sinnilar jurisdictional defense in Matta-Ballesteros's case because the Honduran government did not protest the abduction. Sec Matta-Ballesteros v. Henman, 896 F.2d 255 (7th Cir. 1990), cert. denied, 111 S. Ct. 209 (1990); see infra note 116. 
This Note addresses the validity of the jurisdictional defense raised by the defendants in these two cases. ${ }^{8}$ Although the law in this area is admittedly obscure, this Note argues that the Ninth Circuit erred in several respects in its reasoning in Verdugo II and Alvarez, and that the exigencies of international law enforcement justify the availability of irregular means of gaining custody over fugitives in certain limited cases. The use of such methods is limited to extraordinary cases by the inevitable pohtical and diplomatic repercussions, but in those cases where the executive concludes that the benefits outweigh the disadvantages, the courts have no cause to intervene.

Part I briefly traces the development of the prior law and sets forth the Ninth Circuit's reasoning in Verdugo II. Part I concludes that the court's distimction between the precedents and the facts of Verdugo II is not valid. Part II addresses the Verdugo II court's opinion that extradition treaties provide the exclusive means for gaining custody over fugitives abroad, and concludes that the history and purposes of extradition treaties negate the inference of exclusivity. In Part III, the discussion shifts to the question of whether, assuming that extradition treaties do provide the sole means for acquiring custody, individuals should have standing to claim violations of an extradition treaty as a defense. This Part concludes that if there is any individual standing at all, it exists only when the asylum state specifically protests the exercise of jurisdiction by the abducting state. Finally, Part IV considers the repatriation remedy ordered by the Ninth Circuit and concludes that repatriation is inappropriate. Several other remedies are available to both the abducted fugitive and the asylum state. This Part argues that these alternative reinedies constitute sufficient disincentives to the widespread use of abduction so that the decision to employ the "catch and snatch" method is appropriately left to the executive.

8. The Ninth Circuit's reasoning was fully set forth only in Verdugo II; thus, the discussion will center on that decision. This Note will not discuss the policy considerations that underlie a decision to resort to irregular nieans of gaining custody: Such questions are properly resolved by the executive in the exercise of his foreign policy discretion. See United States v. Curtiss-Wright Export Corp., 299 U.S. 304 (1936). The wisdom of a "catch and snatch" policy is fertile ground for discussion. See, e.g., Abramovsky, supra note 3; Richard Downing, Recent Developnent, The Domestic and International Legal Implications of the Abduction of Criminals from Foreign Soil, 26 STAN. J. INT'L L. 573 (1990). The policy itself is the outgrowth of a 1988 opinion of the Office of the Legal Counsel of the U.S. Justice Department, written by current Attorney General William Barr. The 1988 opinion is not available to the public. See FBI Authority to Seize Suspects Abroad: Hearing Before the Subcomm. on Civil \& Constitutional Rights of the House Comm. on the Judiciary, 10lst Cong., 1st Sess. 3-4 (1989) [hereinafter Seizure Hearing] (stateinent of William Barr). The nore general question of the use of the U.S. military in extraterritorial law enforcentent operations is treated elsewhere in this issue. See Christopher A. Donesa, Note, Protecting National Interests: The Legal Status of Extraterritorial Law Enforcement by the Military, 41 DukE L.J. 867 (1992). 


\section{From Ker to Verdugo II: The Transformation of PRECEDENT}

In an 1886 decision, Ker v. Illinois, the Court establislied that the means by whicl a person comes within the jurisdiction of the court has no effect on the court's power to try him. ${ }^{9}$ Ker was abducted from Peru by a Pinkerton agent wlio, instead of delivering a request for extradition to the Peruvian government, acted on his own initiative to abduct Ker and forcibly return him to the United States for trial. Ker claimed that le had a right to be removed from Peru only in accordance with the provisions of the extradition treaty between the United States and Peru then in force. The Court emphatically rejected tlie argument, characterizing Ker's claim as one of a riglit to asylum. The Court noted that "the absurdity of sucl a proposition would at once prevent the making of a treaty of that kind."10

The Ker position was uniformly followed for over six decades and was reaffirmed by the Court in Frisbie v. Collins. ${ }^{11}$ Frisbie involved a government-autliorized abduction of a fugitive from Illinois by Michigan autlorities. The Court in Frisbie noted that it liad "never departed from the rule in $\mathrm{Ker}$... that tlie power of a court to try a person for crinie is not impaired by the fact that lie had been brouglit within the court's jurisdiction by reason of a 'forcible abduction." "12 The Ker-Frisbie doctrine, as it lias come to be known, lias been a staple of U.S. jurisprudence for over 100 years and lias emerged relatively unscatlied from a series of attacks. ${ }^{13}$

In the face of this continued reaffirmation of the principles set forth in $\mathrm{Ker}$ and its progeny, tle Verdugo II court decided that an abduction in lieu of extradition deprived the court of its jurisdiction. The Nintl Circuit dismissed the governınent's reliance on the Ker-Frisbie doctrine by distinguishing botll Ker and Frisbie from tlie facts in Verdugo II. The Ninth Circuit lield that $\mathrm{Ker}$ stood only for the proposition that a private kidnapping did not violate an extradition treaty. ${ }^{14}$ It relied on dictun in

9. 119 U.S. 436 (1886).

10. Id. at 442 .

11. 342 U.S. 519 (1952).

12. Id. at 522 .

13. See, e.g., Gerstein v. Pugh, 420 U.S. 103 (1975) (rejecting challenge based on due process grounds); United States v. Toscanino, 500 F.2d 267 (2d Cir. 1974) (rejecting challenges based on the U.N. Charter and Charter of the Organization of American States).

14. See United States v. Verdugo-Urquidez (Verdugo II), 939 F.2d 1341, 1346 (9th Cir. 1991), petition for cert filed, 60 U.S.L.W. 3341 (U.S. Oct. 21, 1991) (No. 91-670). The accepted view is otherwise. See, e.g., United States ex rel. Lujan v. Gengler, 510 F.2d 62 (2d Cir. 1975); United States v. Quesada, 512 F.2d 1043 (5th Cir. 1975); United States v. Herrera, 504 F.2d 859 (5th Cir. 1974). 
Ford v. United States, ${ }^{15}$ a case that involved the seizure of a British ship for violation of U.S. prohibition laws. A treaty with Britain provided that such seizures could only occur when the ship carrying the hquor was within one hour's travel from U.S. shores. ${ }^{16}$ The defendants argued that their ship was outside that range, and that therefore the treaty expressly barred their seizure. The Court declined to reach the issue of whether the treaty had been violated, holding that it had been waived. The Court indicated in dictum, however, that the Ker doctrine might not have apphed because, although in $\mathrm{Ker}$ the treaty was not at issue, "[h]ere a treaty of the United States is directly involved, and the question is quite different." 17 This statenient, according to the Verdugo II court, illustrated that the "expansive view" of Ker had not been adopted by the Supreme Court, despite the Frisbie decision's broad language. ${ }^{18}$

The Ninth Circuit dismissed Frisbie as providing "no support for the broad reading of Ker," 19 despite the Frisbie Court's broad affirmation of Ker. The Verdugo II court based its conclusion on two grounds. First, it noted that in Frisbie, no extradition treaty was involved.20 Second, the court found that the rule announced in Frisbie was appropriate

15. 273 U.S. 593 (1927).

16. See Convention for Prevention of Smuggling of Intoxicating Liquors, U.S.-Gr. Brit., May 22, 1924, art. II, § 3, 43 Stat. 1761, 1762.

17. Ford, 273 U.S. at 606.

18. See Verdugo II, 939 F.2d at 1346. The court's conclusion is unwarranted. The treaty involved in Ford expressly stated that "[t]he rights conferred by this article shall not be exercised at a greater distance from the coast of the United States . . . than can be traversed in one hour." Convention for Prevention of Smuggling of Intoxicating Liquors, supra note 16, art. II, § 3, 43 Stat. at 1762. Thus, if the seizure had taken place further away, an express treaty provision would have been violated. By contrast, there was no such violation of a provision of the U.S.-Mexico Extradition Treaty. The Verdugo $I I$ court argued that the lack of an express trcaty violation was irrelevant because, since international law prohibits a violation of another country's territorial sovereignty, there was no need for an express exclusivity provision. See Verdugo II, 939 F.2d at 1352 . The court found that principles of international law are relevant to the interpretation of treaties. Although this is true, the rules of treaty interpretation establish that primary reference is to be made to the clear meaning of the words of the treaty and the intent of the parties. Only where ambiguity remains can recourse be had to other sources of understanding. See $1 \mathrm{M}$. ChÉRIF BASSIOUNI, INTERNATIONAL Extradition: United States LAW ANd Practice 76-80 (2d rev. ed. 1987); Vienna Convention on the Law of Trcaties, opened for signature May 23, 1969, art. 31, reprinted in 8 I.L.M. 679 (1969). As discussed infra Part II, both the words and the purpose underlying extradition treaties unambiguously contradict the theory that extradition is to be the sole method of acquiring custody. The Verdugo II court wrongly dismissed the primary sources of treaty interpretation in favor of general principles of international law.

19. Verdugo II, 939 F.2d at 1347.

20. See id. The court ignored that, although there was no extradition treaty, the Constitution does provide for interstate extradition. See U.S. CoNST. art. IV, § 2, cl. 2; see also 18 U.S.C. § 31813195 (1988). The Court never discussed the Extradition Clause in Frisbie, but it should be noted that the Clause has the same purpose as an extradition treaty, and is akin to a treaty obligation. Appleyard v. Massachusetts, 203 U.S. 222 (1906). The Extradition Clause was intended to facilitate the administration of justice by limiting the rights that the asylum state could confer upon a fugitive: 
only in cases of domestic kidnapping, not international kidnapping. In international cases, "the remedy is apparent: [the fugitive] must be returned to the custody of the government lodging the protest . . . [and then] after he is repatriated, the United States could invoke the extradition process, and depending on the outcome of that process, might be able to obtain jurisdiction over him."21 By contrast, the court argued, in a domestic case repatriation to another state would create an "intractable reinedial problem" because, by law, ${ }^{22}$ states must deliver fugitives to other states upon request. ${ }^{23}$ The court speculated that this remedial problein "may have motivated the decision in Frisbie."24

After dismissing the U.S. government's arguments based on the KerFrisbie doctrine, the Verdugo II court held that extradition treaties provide the exclusive means of acquiring custody over fugitives abroad. It further held that a failure to use the treaty procedures constituted a treaty violation that the defendant could raise to bar jurisdiction, provided that the asylum state protested the violation of its sovereiguty. Part II argues that both of these holdings are inconsistent with the purpose of extradition treaties, which were desigued to accommodate international cooperation in ordinary criminal matters.

\section{Non-Exclusivity of Extradition TREaties}

The Verdugo II court argued that, by entering into an extradition treaty, a state renounces all other methods for acquiring custody over fugitives abroad, in favor of the treaty procedures. ${ }^{25}$ The court held that the detailed procedures set forth in the treaty and the several exceptions to the duty to extradite set forth in Articles Five, Eight, Nine, and Seventeen of the U.S.-Mexico Extradition Treaty inade sense only if the treaty were held to provide the exclusive mechanism. ${ }^{26}$ This Part argues that

"The purpose of the Clause was to preclude any state from becoming a sanctuary for fugitives from justice of another state." Michigan v. Doran, 439 U.S. 282, 287 (1978). This parallels the Court's characterization of extradition treaties in $\mathrm{Ker}$ as "restriction[s] upon the right of the government of the country of the asylum to protect the criminal from removal therefrom." Ker v. Illinois, 119 U.S. 436, 443 (1886). Thus, although there was no extradition treaty involved in Frisbie, it is erroneous to conclude that Frisbie is irrelevant to the facts in Verdugo $I I$.

21. Verdugo II, 939 F.2d at 1347.

22. See 18 U.S.C. $\S 1382$ (1988).

23. See Verdugo II, 939 F.2d at 1347.

24. Id. However, because the rule in Frisbie was merely a reaffirmation of the holding in Ker, which was an international case, this distinction is improbable. Further, it makes no sense to allow a fugitive to benefit from the possibility that the asylum state might not have decided to extradite him, ' given the underlying purposes of extradition treaties. See infra Part II(A). Rather, Ker, Frisbie, and their progeny are directly on point with the facts in Verdugo $I I$.

25. See Verdugo II, 939 F.2d at 1355.

26. See id. at 1350-51. 
the history of extradition and the language of the treaty indicate that the treaty procedures are intended to be one method of judicial assistance, but are not intended to replace all other means of acquiring custody. Exclusivity would defeat the purpose of extradition treaties and is not warranted by the existence of exceptions to the duty to extradite.

\section{A. Exclusivity Would Defeat the Purposes of Extradition Treaties}

The developinent of extradition practice reflects the evolution of international cooperation in criminal matters. Generally, there is no international legal obligation to extradite fugitives. ${ }^{27}$ Historically, extradition was a voluntary limit on the sovereigu's authority to grant asyluin, imposed as a inatter of comity; sovereigns delivered fugitives to each other in the hope that such cooperation would preserve the stability of their own regimes. ${ }^{28}$ Thus, political offenders were the prime candidates for extradition; they were the real threats to stability. ${ }^{29}$ Over time, witl the collapse of monarchies and the rise of more deinocratic forms of governinent, political offenses took on a new character, and extradition evolved into its inodern form of cooperation in criminal matters. ${ }^{30}$ The evolution in the perceived threat to the world order, from pohtical offenses to criminal offenses, is reflected in extradition treaties, ${ }^{31}$ which are designed to assist states in coinbatting crime by setting forth procedures whereby the parties agree in advance to refuse to shelter fugitives duly shown to be wanted by the other state.

The Verdugo II court misunderstood the purposes of extradition treaties, vacillating between two conceptions. First, the court described extradition treaties as "principally desigued to furtlier the sovereigu interests of nations." 32 Four pages later, it found a second purpose - that they are a "means of safeguarding the sovereignty of the signatory nations, as well as ensuring the fair treatinent of individuals." 33 In light of the development of extradition, both of these stateinents of purpose are incorrect. Extradition treaties are desigued to protect neither the sovereignty of nations nor the rights of individuals; ratler, as noted above,

27. 1 Bassiouni, supra note 18 , at 10.

28. For an excellent discussion of the evolution of the concept of extradition, see id. at 5. The Ker Court characterized extradition treaties as a "restriction upon the right of the government of the country of the asylum to protect the criminal from removal therefrom." Ker v. Illinois, 119 U.S. 436, 442 (1886).

29. See 1 Bassiouni, supra note 18 , at 7.

30. Id. at 387; infra text accompanying notes 65-66.

31. The U.S.-Mexico Extradition Treaty, see supra note 6, while refiecting certain specific concerns of the parties, is typical of extradition treaties as a whole, and will be referred to almost exclusively in this discussion.

32. Verdugo II, 939 F.2d at 1346.

33. Id. at 1350 . 
they exist solely to assist the states in preventing and punishing crime. The court's ambivalent and erroneous conception of the nature of extradition led it fundamentally to misinterpret the provisions of the treaty.

As a result of their history and purpose, two different obligations are imposed by extradition treaties. The sole effect on the asylum state is to bind it to dehiver a suspect upon a proper request. ${ }^{34}$ If the requesting state fails to comply with the procedures set forth in the treaty, then the obligation to coinply with the request does not arise. The sole obligation imposed upon the requesting state is that, if it invokes the extradition treaty, it will try the extradited suspect ouly for the specific crime charged. ${ }^{35}$ An extradition treaty thus does not create a reciprocal agreement to use the process provided in the treaty exclusively; rather, it creates two unilateral pledges.

By providing a way for a state to precipitate a legal obligation to coinply with an extradition request, the treaty does not beconie the sole means for obtaining custody. ${ }^{36}$ To illustrate, Article 1 of the U.S.-Mexico treaty provides that " $[t]$ he Contracting Parties agree to mutually extradite" 37 fugitives according to the provisions of the treaty, not that they agree to mutually demand extradition in accordance with the provisions of the treaty. A failure by the requesting state to resort to the treaty procedures thus does not violate the treaty.

The United States might choose not to use the treaty process for a number of possible reasons. In the Alvarez and Verdugo II cases, for exainple, a treaty-based extradition request likely would have been futile because Article Nine of the treaty exempts nationals of the asylum state froin the duty to extradite. ${ }^{38}$ In other cases, the United States might fear that an official extradition request would be futile given the potver of

34. United States v. Sobell, 142 F. Supp. 515, 524 (S.D.N.Y. 1956), aff'd, 244 F.2d 520 (2d Cir. 1957); see also RESTATEMENT (THIRD) OF THE FOREIGN RELATIONS LAW OF THE UNITED STATES $\S 475$ (1987) ("A state party to an extradition treaty is obligated to comply with the request of another state party . . . to arrest and deliver a person duly shown to be sought by that state.").

35. Sobell, 142 F. Supp. at 524.

36. See, e.g., GEOFF GILBERT, ASPECTS OF EXTRADITION LAw 8 (1991) ("[W]hile extradition may be the principal means of rendition, it is only one method by which states may provide mutual assistance in matters of criminal rendition. . . . The overriding aim should be to prosecute whenever a crime has been committed. ... [T] [The use of other means will continue and eannot be ignored."); Alona E. Evans, International Procedures for the Apprehension and Rendition of Fugitive Offenders, 1980 AM. SOC'Y INT'L L. PROC. 274, 276 ("Extradition may be the established method of rendition, but it is by no means a convenient method, or, indeed, a popular method.").

37. Extradition Treaty, supra note 6, art. 1, 31 U.S.T. at 5061 (emphasis added).

38. See id. art. 9, 31 U.S.T. at 5065; infra notes 54-62 and accompanying text (discussing Article Nine). In Matta-Ballesteros's case, an extradition request would have failed because the Honduran Constitution prohibits extradition of nationals. HOND. CONST. art. 102 ("No Honduran may be expatriated nor handed over to the authorities of a foreign state."). Thus, the suspects would have remained in a safe haven, free from proseeution. This type of legal provision is fairly common, 
drug cartels or terrorists and their success in intimidating foreign governments. Or, the United States might fear that the same intimidation would prevent the suspects from receiving a full trial on the charges against thein in the asylum state. ${ }^{39}$

Whatever the reasoning, the U.S.-Mexico Extradition Treaty did not obligate the U.S. government to request extradition in accordance with the treaty procedures; informal methods were available. ${ }^{40}$ Analogizing froin contract law, the Verdugo $I I$ court characterized such imformal agreements as "waivers" of the asylum state's right to insist on strict coinpliance with the treaty procedures. ${ }^{41}$ However, given the history of extradition as a voluntary limitation on the right to grant asyluin, such informal agreeinents are consistent with the comity-based voluntary actions by foreign sovereigns to deny asylum that existed prior to the development of inodern extradition law, and that continue to govern in the absence of treaties.

Analogous support for nonexclusivity coines from the Supreme Court's decision in Société Nationale Industrielle Aérospatiale v. U.S. District Court, ${ }^{42}$ in which the Court concluded that the inechamisms for collecting evidence provided in the Hague Convention on the Taking of Evidence Abroad in Civil or Commercial Matters ${ }^{43}$ were not exclusive of those provided in the Federal Rules of Civil Procedure. ${ }^{44}$ The Court relied upon both the language of the Convention and the goals it was

especially among civil law countries; the United States, Great Britain, and other common law countries typically do not exclude their nationals from the duty to extraditc. GILBERT, supra note 36 , at 95. This exemption of nationals has been justifiably criticized as creating de facto immunity for nationals who commit crimes against foreign interests. See, e.g., id. at 96-97 (noting the imappropriateness of such policies in light of increasingly porous national borders and the proliferation of serious international crimes). This sort of provision may explain why the United States first attempted negotiations for an informal extradition of Alvarez-Machain. See supra note 3.

39. These fears might be legitinately based upon the example of the assassinations of members of the Colombian judiciary by drug lords trying to avoid trial. See, e.g., Ken Dermota, Colombia Gets Plan to Protect Its Judges, WASH. TIMES, Nov. 21, 1990, at A7 (noting 250 judges killed by traffickers and $84 \%$ of cases dropped because of bribes or intimidation). The problem is not limited to Latin America, but extends even to supposedly more stable allies. See, e.g., James M. Markham, Now It's Chirac Who Decides He Can Deal for Hostages, N.Y. TIMEs, Dec. 6, 1987, at D2 (discussing France's "unsavory reputation" for refusing to extradite or try terrorists); Jennifer Parmelee, Italy, U.S. Denounce Release of Suspect; Arab Wanted for Terrorism Freed by Greece, WASH. POST, Dec. 10, 1988, at A.17.

40. There are several informal extradition mechanisms, including deportation, use of immigration procedures, and voluntary delivery in response to a non-treaty-based request. See 1 BAssiounI, supra note 18, at 147-246 (discussing various alternatives to treaty-based extradition).

41. See Verdugo II, 939 F.2d at 1352.

42. 482 U.S. 522 (1987).

43. Opened for signature Mar. 18, 1970, 23 U.S.T. 2555 [hereinafter Hague Evidence Convention].

44. See Société Nationale, 482 U.S. at 541. 
designed to achieve in reaching its conclusion. The Court examined the language of the Convention's preamble, noting that the goal of the Convention was "to facilitate" the collection of evidence and to "improve mutual judicial co-operation." 45 The Court noted that "[t]he preamble does not speak in mandatory terms which would purport to describe the procedures for all permissible transnational discovery and exclude all other existimg practices."46 According to the Court, interpreting the Convention as exclusive would undermine its goals by "effectively subject[ing] every American court ... to the internal laws of [a foreign] state," 47 by making American proceedings contingent on the actions or inactions of foreign judicial authorities.

Based on the langnage and goals of the Convention, the Court dismissed as inconsistent the two contentions that the Hague Evidence Convention was either the exclusive means of obtaining evidence abroad, or a required first resort before using the discovery rules of the Federal Rules of Civil Procedure. The Court concluded that the Convention provided optional procedures that are "available whenever they will facilitate the gathering of evidence... [and] is one method of seeking evidence that a court may elect to einploy," 48 whenever it was appropriate, taking into consideration the interests of the parties before it as well as those of the foreign state. ${ }^{49}$ The parallels between the Hague Evidence Convention and extradition treaties are evident, and a similar interpretation should be adopted for the treaties.

Just as the goal of the Hague Evidence Convention was to facilitate the collection of evidence by providing agreed-upon procedures to suppleinent the haphazard systein that existed before, the U.S.-Mexico Extradition Treaty set up procedures to allow the states to "cooperate more closely in the fight against crime and, to this end, to inutually render better assistance in inatters of extradition." 50 The treaty was established to suppleinent the unrehable pre-existing informal procedures. Neither the Hague Evidence Convention nor the extradition treaty speak in mandatory terms. Further, if the extradition treaty is held to provide the

45. Hague Evidence Convention, supra note 43, pmbl., 23 U.S.T. at 2557.

46. Sociéte Nationale, 482 U.S. at 534. Compare the language of the Hague Convention on Service Abroad of Judicial and Extrajudicial Documents in Civil and Commercial Matters, Nov. 15, 1965, art. 1, 20 U.S.T. 361 [hereinafter Hague Service Convention] ("The present Convention shall apply in all cases ... where there is occasion to transmit a judicial . . . document for service abroad."). The Hague Service Convention has been held to be exclusive. See Volkswagenwerk AG v. Schlunk, 486 U.S. 694 (1988).

47. Société Nationale, 482 U.S. at 539.

48. Id. at 541.

49. See id. at $533,546$.

50. Extradition Treaty, supra note 6, pmbl., 31 U.S.T. at 5061. 
exclusive mechanism for acquiring custody over a fugitive, U.S. criminal proceedings would be held hostage to the internal law of foreign states, thus frustrating the goals of the treaty. Not only could a citizen of a foreign state automatically find a safe haven at hoine when domestic law prohibits extradition of nationals, but the foreign state could simply decide not to extradite, in violation of its treaty obligations. Such a violation would, of course, inake the foreign state hable in international law, but the remedies in such a case would be purely diplomatic and would not address the criminal liability of the sought-after individual.

The significance of the Court's interpretation of the Hague Evidence Convention in Sociéte Nationale and its relevance to the imterpretation of extradition treaties become especially clear when it is recognized that, althougli attorneys typically conduct discovery on their own in the United States, im civil law countries the collection of evidence is a judicial function carried out by the court. ${ }^{51}$ Thus, if a U.S. court authorized the use of the procedures of the Federal Rules of Civil Procedure to collect evidence abroad, it would be committing an affront to that nation's sovereignty. Despite this fact, the Court in Société Nationale found that the courts must weigh the interests of American justice against the imterests of the foreigu state. ${ }^{52}$

A similar approach should be adopted for extradition. To interpret the treaty as constraining the parties to the exclusive use of the treaty mechanism in lieu of other existmg methods of obtaining custody would convert the treaty from a crime-fighting device into a straitjacket for law enforcement agencies. Exclusivity would open up the law enforcement arena to pohtical and diplomatic forces that would underimine the efficiency of the fight aganist crime. Given the political and diplomatic complexities of the extradition process in extremely sensitive cases, the U.S. government must be permitted to conduct a balancing test such as that adopted in Société Nationale to determine whether the interests of justice outweigh the possible diplomatic repercussions of an irregular acquisition of custody.

\section{B. Exceptions to the Duty to Extradite Do Not Warrant an Inference of Exclusivity}

Because there was no textual support for the Ninth Circuit's inference of exclusivity, the court drew its conclusion from Articles Five, Eight, Nine, and Seventeen of the U.S.-Mexico Extradition Treaty, each

51. Société Nationale, 482 U.S. at 543.

52. See id. at 543-44. 
of which contains an exemption from the asylum state's duty to extradite. The court decided that these exceptions made no sense unless the treaty were intended to be exclusive..$^{53}$

The Verdugo II court began its analysis of the exceptions with Article Nine of the Treaty, which exempts nationals of the asylum state from inandatory extradition, even where the requesting state complies with the treaty procedures. ${ }^{54}$ According to the court,

[t]he manifest purpose of Article Nine is to preserve each nation's right not to have its own nationals tried in the courts of the other without its consent. . . . It cannot seriously be maintained that Mexico (or the United States) only wished to preserve the right not to have its citizens formally extradited. ${ }^{55}$

The court thus views Article Nine as a protection of the asylum state's sovereignty.

In fact, there is no such right of a state not to have its nationals tried in the courts of another state without its consent. For example, if Verdugo-Urquidez had been captured in the United States, then Mexico would have had no cause to protest. States clearly have jurisdiction to try individuals found within their territory for crimes over which they have subject-inatter jurisdiction. ${ }^{56}$ Similarly, if Verdugo-Urquidez had been extradited from a third country or captured on the high seas, ${ }^{57}$ then the state of nationality would not have had cause to protest.

Viewed in the context of the goal of international cooperation in criminal matters, Article Nine makes sense as an exception to the extradition obligation designed to avoid a conflict between Mexico's treaty obligation and its domestic law.58 The exemption acknowledges that Mexican law does not permit extradition of nationals, and is included in the Treaty not as part of any "right" of each nation, but to avoid the possibility that use of the extradition procedures will force the asylum state to violate its own domestic law. ${ }^{59}$ The wording of the exception

53. See Verdugo II, 939 F.2d at 1350.

54. Article Nine provides:

1. Neither Contracting Party shall be bound to deliver up its own nationals, but the executive authority of the requested Party shall, if not prevented by the laws of that Party, have the power to deliver them up if, in its discretion, it be deemed proper to do so.

2. If extradition is not granted pursuant to paragraph 1 of the Article, the requested Party shall submit the case to its competent authorities for the purpose of prosecution, provided that Party has jurisdiction over the offense.

Extradition Treaty, supra note 6, art. 9, 31 U.S.T. at 5065.

55. Verdugo $I I, 939$ F.2d at 1350.

56. Schooner Exchange v. M'Faddon, 11 U.S. (7 Cranch) 116 (1822).

57. See United States v. Yunis, 924 F.2d 1086 (D.C. Cir. 1991).

58. Ley de Extradicion Internacional, Diario Oficial de la Federación Mexicana (Dec. 29, 1975).

59. S. ExEC. Rep. No. 21, 96th Cong., 1st Sess. 6 (1979) (letter of submittal). Treaties are tailored to the realities of the domestic law of the particular states. To illustrate, extradition treaties with states that do not have such constitutional or statutory prohibitions, such as Canada and the 
supports this reading; the executive has discretion, "if not prevented by domestic law,"60 to deliver its own nationals. This language envisions the possibility that the Mexican law will be repealed someday as a step toward greater cooperation between states.

Until sucli cooperation is achieved, the Umited States has no clioice but to accept such exceptions in order to gain some sort of international cooperation. ${ }^{61}$ The Umited States correctly views sucl domestic law provisions as equivalent to a grant of immumity by states to its nationals for crimes against other states' interests. ${ }^{62}$ Sucl a de facto grant of immunity to nationals undermines the stated goal of extradition treaties to facilitate cooperation in the figlit against crime. The fact that a particular treaty exempts nationals from extradition does not justify the conclusion that the treaty is intended to be exclusive of other means of rendition; it nerely reflects the imperfect state of cooperation in international criminal affairs.

The Verdugo II court next focused on Article Five, which provides that "[e]xtradition shall not be granted when the offense for which it is requested is political or of a political cliaracter ... [or] a purely military offense."63 The court concluded that this exception also compelled the inference that the treaty mecharrism is exclusive. ${ }^{64}$ The court merely presumed this, without discussing the foundations of the exception, based on its view that extradition is designed to protect state sovereignty and individual rights. The history of the exception belies this conclusion.

The pohitical offense exception only developed in the nineteenth century, witl the rise of democratic governments. ${ }^{65}$ The Ninth Circuit itself has lield that the exception reflects an appreciation of the right of individuals to engage in political activism without fear of retribution, a concern that unsuccessful political activists not be returned to face unfair pumishment on the basis of their political opimions, and the idea that governments should not interfere in the internal pohitical affairs of other states. 66

United Kingdom, do not have exemptions comparable to Article Nine. See, e.g., Extradition Treaty, June 28 \& July 9, 1974, U.S.-Can., 27 U.S.T. 983; Extradition Treaty, June 8, 1972, U.S.-U.K., 28 U.S.T. 227; see also Extradition Treaty, Dec. 10, 1962, U.S.-Isr., art. IV, 14 U.S.T. 1707 (specifically repudiating the exemption for nationals).

60. Extradition Treaty, supra note 6, art. 9, 31 U.S.T. at 5065 (emphasis added).

61. See infra text accompanying note 75 .

62. See 4 Michael A. Abbell \& Bruno A. Ristau, International Judicial AssistANCE: Criminal 67 (1990); supra note 38.

63. Extradition Treaty, supra note 6, art. 5, 31 U.S.T. at 5063-64.

64. See Verdugo II, 939 F.2d at 1350.

65. See supra notes $27-31$ and accompanying text.

66. See Quinn v. Robinson, 783 F.2d 776, 793 (9th Cir. 1986). 
The exception recognizes that an asylum state should not be required either to violate its international legal obligations by refusing to extradite one charged with a "political" offense or to surrender a person who is wanted for an "offense" that is not an offense in the asyluin state. For example, if South Africa requested extradition of Nelson Mandela froin the Umited States for the "offense" of fighting agaimst apartheid, the United States need not coinply. The exception is a inanifestation of one of the basic foundations of extradition law- the double criminality requirement- which requires that acts must be criminal both in the asylum state and the requesting state to fall within the duty to extradite. ${ }^{67}$ Viewed this way, the political offense exception reflects the fact that the goal of extradition is cooperation in criminal affairs.

The Ninth Circuit similarly misinterpreted Article Eight's exception for crimes punishable by death where that crime would not be punishable by death in the asyluin state. ${ }^{68}$ Article Eight provides perhaps the strongest example of an exception designed to benefit the individual. However, the exception inust be viewed in the larger context of crininal cooperation. Althougli states agree to cooperate in the capture and punishinent of criminals, they only agree to do so where the punishinent will fit the crime. If the death penalty is not available in the asylum state, then that state cannot be required to extradite. Whereas the double criminality requirement specifies a certain miminuin purnshinent for a crime necessary to trigger the extradition duty, the death penalty exception is an upper limit. Otherwise, criminal cooperation would blur into cooperation in repression. Article Eiglit reflects a narrow exception to criminal cooperation that serves the same purpose as the double criminality requirement. It does not support a finding of exclusivity.

Finally, the Verdugo II court relied on the rule of specialty embodied in Article 17 of the treaty to support its conclusion of exclusivity. Article 17 provides that "[a] person extradited under the present Treaty shall not be detained, tried or purrished ... for an offense other than that for whicl extradition has been granted nor be extradited by that Party to

67. 1 Bassiouni, supra note 18 , at 325 . The development of the double criminality requirement reflects the desire to minimize the technical demands of extradition, and to remove technicalities as defenses to extradition. Cf. id. at 325-34. Typically, the treaties provide that extradition shall be granted for crimes for which the maximum pumishment in each country is not less than one year imprisonment. See, e.g., Extradition Treaty, supra note 6, art. 2, 31 U.S.T. at 5062.

68. See Extradition Treaty, supra note 6, art. 8, 31 U.S.T. at 5065 ("When the offense . . . is punishable by death under the laws of the requesting Party and the laws of the requested Party do not perumit such punishnent for that offense, extradition may be refused . . . .). Extradition is discretionary under this Article; there is no right of the individual not to be extradited. 
a third State" unless, among other requirements, the asylum state consents to such actions. ${ }^{69}$ Again, the court misinterpreted the treaty because of its flawed understanding of the treaty's purpose. The court here interpreted the treaty as a protection of the individual. The first problem with the court's interpretation of Article 17 is that the exception does not provide that the specialty rule apphies to persons "extradited according to the terms of the treaty,"70 but rather to persons "extradited under the present Treaty."71 Thus, if a person is not extradited at all, for example if he is captured in the United States or dehivered through an informal rendition procedure, the specialty doctrime does not apply at all.

The second problem is that the provision must be seen in the context of the stated purpose of the treaty: to render mutual assistance in criminal inatters. Observed in this context, the specialty rule furthers the goal of inutual assistance. The rule is designed to ensure that a state not be able to trigger the treaty obligation to extradite for one offense only to try the person for a completely different offense that would not have triggered the duty. ${ }^{72}$ For example, if the United States requested extradition of a suspect on the ground of murder and then tried the person for the "crime" of organizing a third political party, then the duty to extradite would have been abused to overcoine the political offense exception. Just as in the case of the political offense exception and the double criminality requirement, the specialty doctrine ensures that the states are actually cooperating in criminal matters, and not abusing the process to further other interests.

The Verdugo II court's rehance on the exceptions to the extradition duty to infer exclusivity was inappropriate. In Société Nationale, the Supreme Court exphicitly refused to infer exclusivity froin the language of the Hague Evidence Convention: "In the absence of exphicit textual support, we are unable to accept the hypothesis that the ... contracting states abjured recourse to all pre-existing ... procedures at the same time that they accepted the possibility that a contracting party could unilaterally abrogate even the Convention's procedures."73 The Supreine Court's reasoning in Société Nationale suggests that if the United States and Mexico had intended to impose unutual obhigations to follow the procedures set forth in the treaty, they could have merely added an exphicit statement to that effect.

\footnotetext{
69. Id. art. 17,31 U.S.T. at 5071 .

70. Verdugo $I I, 939$ F.2d at 1351 (emphasis added).

71. Extradition Treaty, supra note 6, art. 17, 31 U.S.T. at 5071 (emphasis added).

72. This was the case in Umited States v. Rauscher, 119 U.S. 407 (1886), which established the specialty rule. See infra note 77.

73. Société Nationale Industrielle Aérospatiale v. U.S. District Court, 482 U.S. 522, 537 (1987).
} 
After considering all of the exceptions to the extradition duty, the Verdugo II court protested that "[i]t would elevate form over substance to hold that this protection of each sovereign nation's right to insist on strict compliance with the treaty may be circumvented if the other party simply chooses not to invoke the treaty at all."74 The Verdugo II court's misunderstanding of tlie treaty as creating "rights" of the states, other than the right to demand extradition im response to a treaty-based request, forced the court to infer exclusivity to make sense of the treaty provisions. Thus, the court concluded, a failure to utilize tlie treaty procedures constituted a violation of the treaty. When placed in the context of the history and purposes of extradition, the inference of exclusivity is unjustified. To the extent that the goal of mutual assistance in fighting crime is furthered by requesting extradition in accordance with the treaty, tlien tlie requesting state can require tlie asylum state to extradite. If that goal is not best served by requesting extradition, then the requesting state is not obligated to do so. The only legal consequence of a failure to use the treaty procedures is that the asyluin state is not obligated to extradite the fugitive.

If the Verdugo II court's interpretation stands, an unfortunate anoinaly will result. Extradition, like inany other types of international judicial assistance, depends on reciprocity between states. The United States cannot legally extradite a person im the absence of a treaty. ${ }^{75}$ Its inability to reciprocate will prevent otlier states from agreeing to extradite fugitives to the Umited States. To prevent this deterioration of international cooperation, therefore, the Umited States must enter into extradition treaties. Yet according to the Verdugo II court, by doing so the Umited States constrains itself to the exclusive use of those treaty procedures. On the one liand, the United States will have absolute freedom, from the viewpoint of American courts, absent a treaty, to capture fugitives abroad in whatever manner it deeins most desirable. On the other hand, if the Umited States wants to use less diploinatically volatile metlods such as extradition, then it must give up that freedoin.

Instead of contributing to the ability of the United States to punish criminals, the Verdugo $I I$ court's vision of extradition treaties will interfere witl law enforcement. The United States lias entered into extradition treaties to help punish criminals. It makes little sense to reward the individuals in these cases by holding that, by entering into the treaties, the United States has ironically granted tliem a safe haven. The Verdugo II court's conception of extradition treaties thus undermines the very

74. Verdugo $I I, 939$ F.2d at 1351.

75. 18 U.S.C. § 1381 (1988); see also Factor v. Laubenheimer, 290 U.S. 276 (1933). 
goals they are designed to achieve. Extradition treaties were designed with common criminals in mind. They cannot adequately accomplish their goal im the context of terrorism and other sensitive crimes. ${ }^{76}$ In this context, the executive must be permitted the discretion to weigh the various alternatives and decide which is best in a particular case.

\section{INDIVIDUAL STANDING TO RAISE VIOLATIONS OF AN EXTRADITION TREATY}

After arguing that extradition treaties provide the exclusive method of acquiring jurisdiction over a fugitive abroad, the Verdugo II court addressed the question of whether the individual abducted in violation of the treaty could raise that violation as a defense. The court discussed the U.S. government's contention that any such violation was a purely diplomatic issue, but dismissed it based on the holding in United States $v$. Rauscher ${ }^{77}$ that an individual has standing to raise a violation of a specialty doctrine. ${ }^{78}$

This Part argues that the Verdugo II court was wrong in conferring individual standing to raise a violation of an extradition treaty, and that it coinpounded this error by not requiring that the asylum state explicitly demand that the Umited States repatriate the fugitive. Part III concludes that if there is individual standing to raise a violation of an extradition treaty, it exists only when the asylum state explicitly protests the exercise of jurisdiction over the defendant and demands his repatriation. Thus, the court still should have exercised jurisdiction over Verdugo-Urquidez.

\section{A. Extradition Treaties Do Not Confer Standing on Individuals}

International law, both customary and treaty-based, originated as a way for sovereign nations to order their relationships with each other.

76. The political and diplomatic difficulties are most obvious in terrorisin cases. The extradition process works quite well in the case of average criminals. For example, from 1978 to 1987, foreign extraditions grew from 72 to 572, an increase of nearly 800\%. Department of Justice Oversight Hearing, Hearing Before the Senate Comm. on the Judiciary, 100th Cong., 2d Sess. 87 (1988). Irregnlar methods are reserved for the most reprehensible and diplomatically problematic criminals, which weighs against any danger that upholding jurisdiction will unleash a wave of abductions. See infra Part IV.

77. 119 U.S. 407 (1886). Rauscher was handed down on the same day as Ker, and involved the extradition of a defendant from Britain on charges of murder. The United States subsequently sought to try him on charges of cruel and unusual punishment of his victim. Britain protested, and the Court held that Rauscher conld not be tried for any offense other than that for which he was extradited. Rauscher established the rule of specialty, which hinits the crimes for which an extradited fugitive can be tried without the consent of the asylum state. The rule of specialty is explicitly stated in most modern extradition treaties. See, e.g., Extradition Treaty, supra note 6, art. 17, 31 U.S.T. at 5071. The specialty doctrine is discussed supra at text accompanying notes 69-72.

78. See Verdugo II, 939 F.2d at 1355. 
This "peculiar nation-to-nation"79 quality typically prevents individuals from asserting international legal rights. The individual must instead "repair to the executive authorities of his own state to persuade thein to champion his claim in diploinacy or before an international tribunal."80 The traditional view is that states have the sole prerogative to decide whether and how to pursue the coinplaimts of their citizens, and that citizens do not have standing to pursue their coinplaints on their own.

In contrast to general customary international law, a treaty can confer standing on individuals if the parties so intend. ${ }^{81}$ The Verdugo II court concluded that an extradition treaty did confer individual standing, viewing the problem of an alleged violation of the extradition treaty as analogous to a violation of the specialty doctrine. Drawing upon the case of United States $v$. Rauscher, ${ }^{82}$ the court noted that the primary method for enforcing the specialty doctrine is through a challenge brought by the individual. ${ }^{83}$ By imphication, the court reasoned, an individual must have standing to raise a violation of the extradition treaty as a whole, despite the lack of an express treaty provision so providing.

The Verdugo II court claimed that, because the specialty rule prohibits the trying of an extradited person for a crime other than that for which he was extradited, "[i]t follows a fortiori . . . that, if an individual

79. Banco National de Cuba v. Sabbatino, 376 U.S. 398, 422 (1964).

80. Id. at 423; see also RESTATEMENT (THIRD) OF THE FOREIGN RELATIONS LAW OF THE UNITED STATES $\S 713 \mathrm{cmt}$. a (1987) ("In principle, the responsibility of a state ... is to the state of the alien's nationality and gives that state a claim against the offending state. The claim derives from injury to an individual, bnt once espoused it is the state's claim, and can be waived by the state.").

81. See, e.g., Convention for the Protection of Human Rights and Fundamental Freedoms, Nov. 4, 1950, 213 U.N.T.S. 222 [hereinafter European Human Rights Convention]. The European Human Rights Convention can be directly relied upon by individuals in suits against governments. See, e.g., Lawless Case, 1961 Eur. Ct. Human Rights, Ser. A. no. 1. In contrast to extradition treaties, the European Human Rights Convention does not allow a state to waive the human rights of its nationals. See European Human Rights Convention, supra, art. 17, 213 U.N.T.S. at 234.

82. 119 U.S. 407 (1886). For the facts in Rauscher, see supra note 77.

83. Verdugo II, 939 F.2d at 1355 . The circuits are split on the procednre for such a challenge. The Second, Fifth, and Sixth Circuits require a protest by the asylum state before a specialty violation can be raised to bar prosecution; lack of a protest implies a waiver of any objections. Id. at n.13. See Shapiro v. Ferrandina, 478 F.2d 894 (2d Cir.), cert. dismissed, 414 U.S. 884 (1973); United States v. Kaufman, 874 F.2d 242 (5th Cir. 1989); Demjanjuk v. Petrovsky, 776 F.2d 571 (6th Cir. 1985), cert. denied, 475 U.S. 1016 (1986). By contrast, the Eighth, Ninth, and Eleventh Circuits pernnit an extraditee to raise specialty violations even absent a protest by the asylum state; an express waiver of any objection by the asylum state is required to allow such a prosecution to go forward. See Leighnor v. Turner, 884 F.2d 385 (8th Cir. 1989); United States v. Cuevas, 847 F.2d 1417 (9th Cir. 1988), cert. denied, 489 U.S. 1012 (1989); United States v. Diwan, 864 F.2d 715 (11th Cir.), cert. denied, 492 U.S. 921 (1989). In any event, the consequence of a specialty violation is a refusal to exercise jurisdiction only with regard to crimes other than those forning the basis for the extradition. The courts will still exercise jurisdiction for the crimes for which the person was extradited. A violation of the specialty doctrine does not require repatriation of the fugitive. 
has been kidnapped by a treaty signatory-i.e., if he has not been extradited for any offense at all-he may not be detained, tried, or punished for any offense without the consent of the nation from which he was abducted." 84 This extrapolation reflects the Verdugo II court's erroneous conception of the purpose of extradition treaties as a "means of safegnarding the sovereignty of the signatory nations, as well as of ensuring fair treatinent of individuals." 85 The court concluded froin the individual's enforcement of the specialty doctrine that the individual had standing to raise a violation of the treaty as a whole.

However, the mere fact that an individual has a right to enforce the specialty doctrine does not mean that the treaty is intended to confer standing upon him. Instead, the fact that the individual only has the right to raise the issue of a treaty violation, as opposed to the right to insist on a particular outcome, indicates that the real center of interest is the asylum state: Extradition treaties, including their various "restrictions, limitations, or defenses . . . are not . . . primarily designed for the benefit of individuals. Instead, they are designed to inure to the benefit of the states involved." 86 The specialty enforceinent mechanisin reflects the idea that, because the person might not have been extradited for other crimes, he is present before the court only for the purpose of being tried for the crimes for which he was extradited. ${ }^{87}$ The courts allow the individual to raise the specialty violation because otherwise the asylum state could be deceived into extraditing a fugitive for a crime for which the asyluin state would not have ordinarily extradited him.

In contracting away soine of their discretionary right to grant asylum, the parties to a treaty do no more than specify procedures for determining whether to deny asylum in a particular case. These procedures are designed to ensure that a state's agreenent not to exercise its right to grant asylum is well-founded. The specialty doctrine, like the double criminality requirement and the pohitical offense exception, is designed not to protect the individual, but, in keeping with the nation-to-nation character of international law, to protect the integrity of the asyluin state's decision to extradite. ${ }^{88}$ Failure to coinply with the treaty obligations therefore does not confer any rights upon which the individual can insist, except when the domestic law of the requesting state permits it. ${ }^{89}$

84. Verdugo II, $939 \mathrm{~F} .2 \mathrm{~d}$ at 1355.

85. Id. at 1350 .

86. 2 BASSIOUNI, supra note 18 , at 629 .

87. See United States v. Rauscher, 119 U.S. 407 (1886); 4 ABBell \& RIsTAU, supra note 62, at 333.

88. See 1 BASSIOUNI, supra note 18, at 360; supra notes $63-72$ and accompanying text (discussing how the various extradition limitations protect the integrity of the extradition decision).

89. 2 BASSIOUNI, supra note 18 , at 630 . 
By interpreting the specialty doctrine to mean that an individual who is not extradited cannot be tried for any crime at all, the court skewed estabhshed law on the rights of individuals in international law. Extradition treaties must be read to further their stated goal of cooperating in the efficient fight against crime. ${ }^{90}$ By allowing the defendants to raise the violation of the extradition treaty as a defense, the Verdugo $I I$ court again undermined the purpose of the treaty.

\section{B. Any Individual Standing Must Depend on an Adequate Protest by the Asylum State}

After deciding that an individual might have standing to raise a violation of an extradition treaty as a defense, the Verdugo II court held that the asylum state's protest of the abduction was critical to the existence of standing. 91

90. See Vienna Convention on the Law of Treaties, opened for signature May 23, 1969, art. 31, 8 I.L.M. 679 ("A treaty shall be interpreted in good faith in accordance with the ordinary meaning to be given to the terms of the treaty in their context and in the hight of its object and purpose.").

91. The court noted that no case had ever addressed the issue of whether an abduction combined with a protest by the asylum state would constitute a violation of an extradition treaty that could be raised by the individual. See Verdugo II, 939 F.2d at 1346. According to the Verdugo II court, however, several cases "suggested" that there would be a violation that would confer standing. See id. at 1346, 1349 n.9. The court cited Matta-Ballesteros v. Henunan, 896 F.2d 255 (7th Cir.), cert. denied, 111 S. Ct. 209 (1990); Umited States v. Zabaneh, 837 F.2d 1249 (5th Cir. 1988); United States v. Cordero, 668 F.2d 32 (1st Cir. 1981); Umited States v. Reed, 639 F.2d 896 (2d Cir. 1981); United States v. Valot, 625 F.2d 308 (9th Cir. 1980); and Waits v. McGowan, 516 F.2d 203 (3d Cir. 1975 ) as supporting this proposition. For example, the court in Reed stated that "absent protest or objection by the offended sovereign, Reed has no standing to raise a violation of international law as an issue." Reed, 639 F.2d at 902 (citing United States ex rel. Lujan v. Gengler, 510 F.2d 62 (2d Cir. 1975)). The Lujan court, however, was referring not to petitioner's claim of a violation of the extradition treaty, but to his clains of violations of the U.N. Charter and the Charter of the Organization of American States. See Lujan, 510 F.2d at 67. On the issue of a violation of the extradition treaty, by contrast, the Lujan court referred to United States v. Sobell, 244 F.2d 520 (2d Cir. 1957), which held that an abduction did not violate an extradition treaty. See Lujan, 510 F.2d at 66; see also Sobell, 244 F.2d at 524. The Reed court thus misunderstood Lujan. Lujan stands only for the proposition that where the plaintiff clains a violation of general international law, the asylum state must protest to confer standing upon the individual. With regard to extradition treaties, Lujon specifically held that an abduction did not constitute a violation; thus the issue of a protest was irrelevant. Therefore, the Verdugo II court's reliance on Reed for support of its proposition that an abduction combined with a protest constituted a violation of the extradition treaty conferring stand. ing was misplaced.

In fact, two courts have directly addressed the effect on the court's jurisdiction of a protest in combination with a violation of an extradition treaty. Both have found that the protest had no effect upon jurisdiction. In Government of Jamaica v. United States, 770 F. Supp. 627 (M.D. Fla. 1991), the Jamaican government coinplied with an extradition request by the United States, only to dis. cover after rendition that the defendant's notice of intent to appeal the extradition order had been placed in the wrong file. Jamaica filed an official protest, alleging that the extradition was illegal under Jamaican law because it occnrred before the appeal of the extradition decision, and thus vio. lated Article 8 of the U.S.-Jamaica Extradition Treaty, which required that extradition be carried out in conformance with the dornestic laws of the parties. Id. at 630 n.5. Jamaica deinanded the 
The most serious problem with the court's protest requirement is that it apparently sets no minimum threshold for the type of protest that will strip the courts of jurisdiction. ${ }^{92}$ The disparate responses of the Mexican government to the abductions of Alvarez-Machain and Verdugo-Urquidez illustrate the problem. In Alvarez-Machain's case, Mexico immediately and emphatically protested the abduction and demanded his return for trial in Mexican courts. ${ }^{93}$ The court noted that several specific formal diplomatic protests had been made, that Mexico had unequivocally claimed that the abduction had violated the extradition treaty, and had "at all times demanded his immediate repatriation to Mexico."94 The Alvarez court distinguished the Mexican protest froin that in Verdugo II.95 In Verdugo-Urquidez's case, Mexico's response was more ambiguous. Mexico lodged a "formal complaint regarding the kidnapping" three months after the abduction, and requested that "U.S. judicial authorities" be notified of the complaint. ${ }^{96}$

Despite the qualitative difference in the Mexican response in each case, the Verdugo II court stated that the "clear purpose of the letter [m Verdugo-Urquidez's case] was to call the court's attention to the Treaty violation and the court's resulting lack of personal jurisdiction over Verdugo and to provide the requisite foundation for proceedings leading

defendant's repatriation. The court held that, despite the violation of the extradition treaty and the Jamaican government's demand, the only remedy was through the diplomatic process. See id. at 633. In an older case, Ex parte Lopez, 6 F. Supp. 342 (S.D. Tex. 1934), the petitioner claimed he had been abducted from Mexico in violation of the extradition treaty. The Mexican government intervened in the case, raising the same claims as petitioner, and requesting that he be returned to Mexico, whereupon Mexico would entertain an extradition request. Id. at 343. The court held that, although the Mexican government's intervention raised serious questions, those questions were properly left to the executive branch to resolve, and the courts had no jurisdiction to entertain them. Id. at 344.

92. A further problem is that the Ninth Circuit was imconsistent in its apphication of the rule it created. After discussing the split between the circuits as to whether a protest is required to permit the individual to raise the specialty violation, see supra note 83 , the court adopted the approach of the Second, Fifth, and Sixth Circuits, holding that, although the Ninth Circuit does not require a protest to raise a specialty violation, in the case of a kidnapping, there must be a formal protest from the asylum state's government. Verdugo II, 939 F.2d at 1356-57. The court did not explain the different treatment it gave the two situations. Indeed, the court indicated that the reasons for allowing a defendant to raise the violation is even inore compelling in abduction than in specialty cases. See id. at 1356. There is no apparent logical reason for requiring a protest in one situation while not requiring it im another.

93. Larry Roliter, Mexico Arrests Six in Abduction Case, N.Y. TIMES, Apr. 29, 1990, at A9.

94. United States v. Alvarez-Machain, 946 F.2d 1466, 1467 (9th Cir. 1991), cert. granted, 60 U.S.L.W. 3376 (U.S. Jan. 10, 1992) (No. 91-712).

95. See id.

96. Verdugo $I I, 939 \mathrm{~F} .2 \mathrm{~d}$ at 1343. 
to the granting of the appropriate judicial relief."97 Accepted practice loolds that if a state wishes repatriation of a suspect abducted from its territory, it must explicitly demand his return. ${ }^{98}$ If Mexico had intended that the protest in Verdugo II be taken as an attempt to "lay the foundation" for a judicial determination that jurisdiction did not exist, then the government could have explicitly demanded Verdugo-Urquidez's return. Mexico clearly knew low to do so, as slown by the protest in AlvarezMachain's case. Judge Browning partially dissented in Verdugo II because of the vast difference in the Mexican response to the two abductions, notimg that the difference in the two protests "is striking and may well be significant." 99 Judge Browning's dissent correctly emphasized the difficulty of attempting to divime the true meaning of a foreign state's ambiguous protest. The Verdugo II court's requirement of a protest in the case of a kidnapping (while mexplicably not requiring one in a specialty case) is not workable. Many diplomatic and domestic political reasons may account for a particular method of protest. ${ }^{100}$

97. Id. at 1360. The court failed to explain how the Mexican government would have surmised that the court would in fact require such a protest, given that no other court had ever found that an abduction had violated an extradition treaty. See supra note 91.

98. Restatement (ThiRd) OF THE Foreign RElations LAW OF THE UNITED STATES $\S 432 \mathrm{cmt}$. c (1987) ("[T]he state from which the person was abducted may demand return of the person and imternational law requires that he be returned. If the state . . . does not demand his return, under the prevailing view the abducting state may proceed to prosecute him under its laws.") (emphasis added); id. reporter's note 3 ("[S]tates ordinarily refrain from trying persons illegally brought from another state only if that state demands the person's return.") (emphasis added).

99. Verdugo II, 939 F.2d at 1368 (Browning, J., concurring in part and dissenting in part). The majority in Verdugo II disagreed with Judge Browning's partial dissent, which he based upon the language of the Restatement, claiming:

[W]hat the authors of the Restatement mean by "demand his return" is far different from what Judge Browning suggests. The Reporter's Note . . . uses as illustrations of what is required the cases of individuals who were returned on the basis of a simple "protest," and not of an express unequivocal repatriation "demand" by the government of the offended nation.

Id. at 1360-61 n.22. The majority is incorrect. Although the Reporter's Note first used the word "deinand" and then immediately stated that "[i]n a number of cases, protest by the offended state resulted in the release or return of the accused person," RESTATEMENT (THIRD) OF THE FOREIGN RELATIONS LAW OF THE UNITED STATES $§ 432$ reporter's note 3 (1987) (emphasis added), both of the referenced cases were, in fact, actually cases of an explicit repatriation demand, not a mere protest. See Lawrence Preuss, Note, Kidnaping of Fugitives from Justice on Foreign Territory, 29 AM. J. INT"L L. 502, 503 (1935) (In the Jacob case, "[t] the immediate return of Jacob, the purishment of the guilty functionaries, and the taking of steps necessary to prevent the recurrence of like incidents."); Note of the Federal Council to the German Foreign Office, Apr. 1, 1935, reprinted in JouRNAL DE GENEVE, Apr. 3, 1935; Swiss Make Issue of Nazi Kidnapping, N.Y. TIMES, Apr. 3, 1935, at 1; see also Casablanca Case (Fr. v. Ger.), 1 Hague Ct. Rep. (Scott) 110, 110 (1909).

100. See, e.g., Row over DEA Snatch Caper; Doctor Abducted and Flown to Stand Trial in the U.S., LATIN AM. WKIY. REP., May 3, 1990, at 4 ("Mexico's efforts [in the Alvarez case] seem directed more towards finding those responsible for the snatch than towards getting the physician back."). 
By finding that all that is needed to void jurisdiction is a protest of the nature of that filed in Verdugo-Urquidez's case, the court placed the asyluin state in a dilemma. In light of the Verdugo II holding, the asyluin state has three choices: 1) clearly protest a violation of its sovereignty and demand repatriation, thereby voiding U.S. jurisdiction and being forced to take back the suspect; 2) ignore the violation altogether; or 3) protest ambiguously and allow the U.S. courts to decide what was ineant. The contrast between the Mexican government's responses to the Alvarez-Machain and Verdugo-Urquidez abductions lends credence to the U.S. government's view that Mexico intended the letters to lead to a diplomatic resolution of the Verdugo-Urquidez matter. ${ }^{101}$ The court should have adopted Judge Browning's view that any protest inust clearly demand the return of the suspect to void the court's jurisdiction. This would permit the full range of diplomatic remedies, discussed in Part IV, while preserving the versatility states need to respond to changing circumstances.

\section{REMEDIES}

By finding that Mexico's protest in Verdugo's case was sufficient to strip the court of jurisdiction, the Verdugo II court reinoved the flexibility that governments need to manage the diplomatic effects of an irregnlar rendition. By forcing the offended state to choose between not protesting at all and taking back the suspect, the court ignored the alternative remedies already available to the state and to the individual. A repatriation reinedy elevates the process over the result intended by the parties. As noted previously, the extradition treaty is designed to promote efficiency in the administration of justice, not to permit criminals to escape by finding a safe haven in another country. ${ }^{102}$

The repatriation remedy is not only mconsistent with the goals of extradition treaties, but is also inconsistent with Supreme Court doctrine with regard to illegal arrests. The Court has definitively rejected the idea that a defendant's body is a suppressible "fruit of the poisonous tree." Two recent cases, United States v. Crews ${ }^{103}$ and INS v. Lopez-Mendoza ${ }^{104}$ specifically rejected any possibility that such a claim survived Ker and Frisbie, concluding that "[t] he 'body' . . . of a defendant . . . is never itself suppressible as a fruit of an uulawful arrest." 105 The Verdugo

101. See Verdugo II, 939 F.2d at 1360.

102. See supra Part II(A).

103. 445 U.S. 463 (1979).

104. 468 U.S. 1032 (1984).

105. Id. at 1039; see also Matta-Ballesteros v. Henman, 896 F.2d 255, 263 (7th Cir. 1990) ("While we do not condone government misconduct such as Matta alleges, we cannot create an 
II court relegated Lopez-Mendoza and Crews to a footnote and distinguished them on the grounds that their holdings were not applicable to a violation of a treaty, but only to a violation of the U.S. Constitution. ${ }^{106}$ In so doing, the court apparently elevated treaty law above the U.S. Constitution: "[E]xtradition treaties set forth mandatory procedures that must be followed .... Therefore, failure to comply with an extradition treaty affects the jurisdiction of the court in a way that a typical illegal arrest-even if im violation of the Constitution-does not." 107

There are more appropriate remedies available if an abduction is held to be illegal, all of which are well-established. The most obvious alternative remedy is for the states to deal with the problem on the diplomatic level, where such disputes have traditionally been resolved. The abducting state can be pressured into issuing an apology to the offended state, as done in the case of the abduction of Adolph Eichmann from Argentina by Israel. ${ }^{108}$ Another remedy, exphicitly recognized by the Supreme Court in Ker, is for the abducted fugitive to sue his abductors in U.S. courts. ${ }^{109}$

A more serious remedy, and one that could act as a strong deterrent to a policy of abduction, is for the offended state to deinand that the United States extradite the kidnappers to stand trial on charges of kidnapping. ${ }^{110}$ In fact, Mexico did exactly that in the Alvarez-Machain matter. ${ }^{111}$ A refusal to extradite the kidnappers might jeopardize international cooperation in a variety of areas. ${ }^{112}$

exclusionary rule for the person of the defendant $\ldots$ in the face of repeated affirmation by the Supreme Court that no such rule exists.").

106. See Verdugo II, 939 F.2d at 1347 n.7. The court dismissed several other cases in the same manner.

107. Id.

108. See U.N. SCOR, 15th Sess., 868th mtg. at 1, U.N. Doc. S/4349 (1960). After "private bounty hunters" kidnapped Eichmann, a Nazi war criminal, from Argentina, a flurry of diplomatic activity resulted. Argentina protested to the U.N. Security Council, which condemned the abduction. Israel subsequently apologized for the mcident, and the matter was declared closed; Argentina never demanded Eichmann's repatriation.

109. See Ker v. Illinois, 119 U.S. 436,444 (1886); see also Extraterritorial Apprehension by the Federal Bureau of Investigation, 4B Op. Off. Legal Counsel 543, 554-55 (1980) (noting the potential civil liability of federal officials for false imprisonment, false arrest, and assault and battery).

110. See Seizure Hearing, supra note 8, at 25 (statement of Abraham D. Sofaer); see also Ker, 119 U.S. at 444 (noting that treaty with Peru provided for extradition of persons charged with kidnapping).

111. Mexico Wants U.S. to Extradite Pair, CHI. TRIB., July 22, 1990, at 16.

112. See, e.g., Rohter, supra note 93 (reporting that Mexico threatened to suspend cooperation in efforts to halt drug trafficking). 
If the rule in Verdugo $I I$ and Alvarez stands, fugitives abroad need not fear being brought to justice, especially where the asylum state forbids extradition of nationals. As DEA Administrator Robert Bonner asserted, "[t]he inplications of the [Alvarez] case are that anyone who can get a foreign government to issue a note of protest niay have a ticket out of prosecution, conviction and sentencing in the United States."113 The decisions import into U.S. law a provision of foreign law giving de facto immunity to nationals, which the United States condemns, directly in conflict with the Court's adnionition in Ker that "it is idle . . . to claim that, either by express terms or by implication, there is given to a fugitive ... any right to remain and reside in the [asylum state]." 114 The Crews Court indicated that, $m$ determining the impact of an illegal arrest, a balance nuust be struck between the administration of justice and the constitutional rights of individuals:

Our numerous precedents ordering the exclusion of such illegally obtained evidence assume implicitly that the remedy does not extend to barring the prosecution altogether. So drastic a step might advance marginally some of the ends served by exclusionary rules, but it would also increase to an intolerable degree interference with the public interest in having the guilty brought to book. ${ }^{115}$

The Verdugo II court ignored this balance. The court's repatriation remedy seriously imterferes with the public interest in trying people suspected of committing serious crimes.

\section{CONCLUSION}

In cases of terrorism and other pohtically sensitive international crimes, governments should not be unnecessarily hampered in their pursuit of the essential goal of all criminal law- to pumsh the guilty. The decision to request extradition according to the treaty procedures or to pursue a different method of acquiring custody is a decision that the executive must make after weighing the seriousness of the crime, the likehhood of a formal extradition, and the imterest of the United States im punishing the gnilty. ${ }^{116}$ Successful trial and conviction is the only possible way to discourage such crimes, especially when those crimes are part

113. Philip Shenon, Drug Chief Defends Abduction of Mexican Doctor, N.Y. Times, Aug. 29, 1990 , at 18 (quoting Bonner).

114. $\mathrm{Ker}, 119$ U.S. at 442.

115. United States v. Crews, 445 U.S. 463,474 n.20 (citation omitted).

116. See Seizure Hearing, supra note 8 , at 8 (statement of William Barr). The question is undoubtedly fraught with the danger of severe repercussions abroad. The U.S. embassy in Honduras was the site of riots for days following the abduction of Matta-Ballesteros, even in the absence of a protest by the Honduran government. See Popular Response, LATIN AM. WKIY. REP., Apr. 21, 1988, at 4. Matta-Ballesteros unsuccessfully sought to use this "protest by the people" as equivalent to a protest by the government, in order to raise the same defense as Verdugo-Urquidez and Alvarez- 
of the foreign policy of some foreign states. A society has the inherent right of self-defense. ${ }^{117}$ When crimes strike at a society's foundations, the society must be able to fight back. Once they are captured, the suspects will have all the protections of the Due Process Clause.118

The diplomatic and other drawbacks of a "catch and snatch" policy are sufficient to inhibit the use of such tactics except in the inost extreme cases; forcing repatriation of fugitives who would otherwise go unpunished for their crimes goes too far. ${ }^{119}$ The Supreme Court should reverse the Ninth Circuit's holdings in Alvarez and Verdugo II, and hold that an abduction does not violate an extradition treaty so as to strip the courts of jurisdiction to hear legitimate criminal cases.

Machain. See Matta-Ballesteros v. Henman, 896 F.2d 255, 259-60 (7th Cir. 1990). In addition, the Iranian Parliament passed a law authorizing its police to abduct Americans abroad sliortly after the Justice Department issued its 1988 opinion. See Iran Bill Allows Arrest of Americans Who Offend Nation, L.A. TimES, Nov. 1, 1989, at A7.

117. U.N. CHARTER art. 52.

118. See United States v. Verdugo-Urqnidez (Verdugo I), 494 U.S. 259 (1991). In light of the Court's holding in Verdugo $I$ that the extent of an alien's protection under the Constitution depends on the link between him and the American society, that should be the extent of courts' concern.

119. Cf. INS v. Lopez-Mendoza, 468 U.S. 1032, 1050 (1984) (" "There comes a point at which courts, consistent with their duty to administer the law, cannot continue to create barriers to law enforcement in the pursuit of a supervisory role that is properly the duty of the Executive and Legislative Branches.' That point has been reached here.") (quoting United States v. Janis, 428 U.S. 433, 459 (1976)). 